\title{
Hindutva, Economic Neoliberalism and the Abuse of Economic Statistics in India
}

Jayati Ghosh

\section{(2) OpenEdition}

\section{Journals}

Electronic version

URL: https://journals.openedition.org/samaj/6882

DOI: $10.4000 /$ samaj.6882

ISSN: 1960-6060

\section{Publisher}

Association pour la recherche sur l'Asie du Sud (ARAS)

Electronic reference

Jayati Ghosh, "Hindutva, Economic Neoliberalism and the Abuse of Economic Statistics in India", South Asia Multidisciplinary Academic Journal [Online], 24/25 | 2020, Online since 18 November 2020, connection on 21 April 2022. URL: http://journals.openedition.org/samaj/6882 ; DOl: https://doi.org/ $10.4000 /$ samaj.6882

This text was automatically generated on 21 April 2022.

\section{(c) $($ ) $(9)$}

This work is licensed under a Creative Commons Attribution-NonCommercial-NoDerivatives 4.0 International License. 


\title{
Hindutva, Economic Neoliberalism and the Abuse of Economic Statistics in India
}

\author{
Jayati Ghosh
}

1 Hindutva is a term of relatively recent vintage, first used by the rightwing Hindu ideologue V. D. Savarkar in the 1920s, but gaining wider public recognition only from around the late 1980s, when it was adopted enthusiastically by the currently ruling Bharatiya Janata Party (BJP). The ideology of Hindutva claims to be inclusionary but is fundamentally exclusionary, privileging the majority Hindu community and aiming for Hindu dominance (that too based on a particular strand of Hinduism that does not acknowledge the vast plurality of faiths and doctrines even within that religion). The proponents of Hindutva wish to move politically towards a "Hindu Rashtra," a state ruled by and for Hindus, where those professing other religions may or may not be tolerated and accepted as citizens, and would certainly not be treated as equal to Hindus. We know-and are now being made to experience in all sorts of unpleasant and even dreadful ways-that it is also a vision that is fundamentally incompatible with democracy; and that it leads to various forms of violence, with impunity of the perpetrators, and injustice towards those perceived as "others."

2 Neoliberal economics is generally seen as the theoretical framework underpinning economic policies of liberalization, privatization and deregulation of markets. However, it is wrong to see it as requiring a withdrawal of the state or even a reduction of its role in the economy; rather, it is a shift in the orientation of the state to protect and enhance the interests of large capital in its various manifestations. Therefore, even as it claims to be pro-market, it does not hesitate to use government intervention when that serves the interests of large capital. 


\section{Is there an economics of Hindutva?}

3 On the face of it, Hindutva may seem antithetical to the contemporary neoliberal globalization evident globally since the early 1990s and which places markets and the rule of capital above any social norms that divide people according to other criteria. But here is the contradiction: the Modi government, which is now more openly declaring its Hindu majoritarian and Hindu nationalist instincts, is also unabashedly neoliberal and pro-big capital, including global capital.

4 So, is there such a thing as Hindutva economics? Nothing in the writings of the original advocate of Hindutva, Vinayak Damodar Savarkar, provides any clear economic vision or economic model. Within the Sangh Parivar, only the Swadeshi Jagran Manch, which is unabashedly "nationalist" in its perspective, has any clear position on most economic issues. This mostly reflects a relatively unthinking protectionist approach, which is typically not combined with any systematic industrial strategy, so it does not really enable systematic structural change. Several other elements within the Sangh Parivar, as well as the fringe groups that it periodically disowns even while implicitly encouraging them, have socio-cultural agendas that also affect the economy, often adversely. These agendas are nevertheless privileged and given importance because of the wider social, political and cultural connotations.

5 Thus, for example, "Gau Raksha" (or protecting the cow, since this animal is worshipped as being holy by some Hindus) as recently popularized, encouraged and enabled by some leaders of the ruling party at the central and state government levels, has turned out to be an unmitigated economic disaster. Not only has Gau Raksha attacked the livelihoods (and in some cases lives) of livestock traders (who tend to be disproportionately Muslim or from lower castes), it has also destroyed India's once flourishing beef export industry and the leather industry, which employed lakhs of people. Meanwhile, it has made it uneconomic to hold cattle after they stop being useful for milking, which has led to farmers simply releasing cows to forage on their own. The abandoned cattle have thus become a threat to farming itself, as they seek to survive by foraging off existing cultivated fields. State governments, like Uttar Pradesh, that have put cow protection high on their agenda, are now forced to spend vast amounts to build and run cow shelters, which are still inadequate for the need. Clearly, this is one aspect of the current manifestation of Hindutva that serves absolutely no economic purpose and does actual material harm.

6 Similarly, the tendency of many proponents of Hindutva to glorify and exaggerate claims of scientific knowledge in ancient (supposedly "Hindu") India may appear laughable, but they have serious consequences in terms of undermining both scientific training and the use of scientific knowledge in all aspects of life, from medicine and health to agricultural practices to industrial innovation. During the Covid-19 pandemic, for example, even official health ministries and institutions have issued problematic statements about the preventive or curative properties of particular diets, of imbibing cow urine, and other ideas that ought to be recognized as wacky rather than scientific. This represents not only an immediate cost: the associated lack of development of science and technology in the country could lead to a setback that would last for many years and have generational impact.

7 There are many other ways in which Hindutva actively acts against economic activity, but some have more complex distributional effects. Communal riots are dreadful and 
ghastly events that bring out the worst in people and cause untold harm to lives, property and daily life. They lead subsequently to possible physical displacement as well as a climate of fear and suppression that can hardly be conducive to economic activity. Riots-often instigated cynically by proponents of Hindutva for political and other purposes-are clearly not economically beneficial in the aggregate. However, they can sometimes lead to benefits for particular communities, if they succeed in displacing others from lands, assets, livelihoods. This is known to have happened in Gujarat after the 2002 riots when Muslim entrepreneurs and traders were forcibly displaced or left of their own accord because of fear of further violence, and their assets and income opportunities were taken over by Hindus. Similar processes have occurred elsewhere, for example after the Muzaffarnagar riots in 2013, and are now being openly encouraged in Uttar Pradesh.

8 This complexity provides an inkling of how Hindutva might actually fit in with a neoliberal capitalist economic agenda, despite the other contradictions noted earlier. It is worth noting that the ideologues of Hindutva rarely if ever refer to distributional justice or improving the lot of the poor. The focus is aspirational, even while seeking to disguise the facts that the poor exist because of the rich and their actions, and that all economic policies have distributive results. The attempt of Hindu nationalism is to unify one group (which happens to be in a majority) and exclude, marginalize or even persecute and oppress those who are not members of this group, even those who are sometimes seen as within the broader "Hindu" religious fold like Sikhs and Buddhists. This unification occurs on the basis of notions of national pride centered around a powerful leader, who can then set goals that may be vacuous (such as Prime Minister Modi's declared goal of reaching $\$ 5$ trillion GDP by 2025 , which made little sense even when it was announced in 2019 and is now in any case unachievable) but somehow give vicarious satisfaction.

Of course, all this is deeply undemocratic, but it has become clear-and not only in India-that neoliberal financial globalization is also incompatible with democracy, essentially because it undermines living standards of the bulk of the people and therefore requires that they be controlled politically in various ways. As a result, in a peculiar way, while the ideology of Hindutva seems to be contradictory to a modern economy, it actually fits in quite well with the functioning of neoliberal capitalism. As the country and its polity move rapidly towards the goal of Hindu Rashtra, the oppressive embrace of economic neoliberalism directed by global capitalism also persists.

In this scheme of things, even as people grow poorer and more insecure, they can bask in some belief that the economy is doing very well, even if it is not; and that their own poor condition is the result of their own shortcomings or bad karma rather than because of the failure of public policy. Propagation of such beliefs serves neoliberalism very well. Even as income and asset distribution get worse, even as poor people face displacement, material insecurity and terrible conditions without social protection, they can be diverted to thinking about other things and thereby allow this state of affairs to continue. Their economic concerns can be subordinated to "national pride" and "Hindu pride." Meanwhile those who protest or seek to mobilize against this can be conveniently labelled as "terrorists" and "anti-nationals" and locked up under various laws, which fits in with the broader argument that neoliberalism is generally forced to become anti-democratic. 
11 However, this also requires that the majority of the affected population be kept unaware that the deterioration of their individual material circumstances is not unusual, nor the fault of their personal circumstances or bad karma. In other words, the true state of the economy and of people's livelihoods within them must be disguised, to prevent a more widespread understanding of the extent of economic calamity or the role of public policies in creating or adding to it, or the growing inequalities that are being allowed to fester.

\section{The manipulation and destruction of economic statistics}

12 This is the context that explains why the Modi government has been so proactive in the manipulation and destruction of the statistical system, which was once one of the best and most reliable in the developing world. The aggressive attitude towards economic statistics - and indeed to all data that could provide some semblance of accountability for the government-has become one of the defining features of the government.

13 This has been reflected in several ways, most notably the suppression and then politicization of the National Statistical Commission, which was originally envisaged as an independent body of experts which would verify and supervise the collection, collation and dissemination of official data, but has become increasingly subservient to the political masters. The Central Statistical Organisation, the body that collects and disseminates data, which is run and staffed by professional economists and statisticians, has also lost credibility because of the blatantly political attempt to manipulate official data.

14 The most obvious such effort has related to measures of Gross Domestic Product (GDP, the most commonly used indicator of economic activity). It is true that the very concept of GDP even as a measure of material well-being is deeply flawed, and in countries like India, the measurement of economic activity itself is subject to all sorts of assumptions, given the importance of informal activity. However, the Modi government has sought to use the periodic revision of the base year for estimation of GDP (to the base 2011-2012) to change the methodology in ways that render the data suspect. One significant change was the shift from using the Index of Industrial Production (a real measure of output) as one of the primary indicators of industrial GDP to using data from company reports compiled by the Ministry of Corporate Affairs. That database is seriously flawed: with a significant proportion (around one-third) of dummy companies, it shows very wide fluctuations; and is likely to reflect incentives for companies to misstate their returns, especially in quick estimates (Nagaraj 2015, 2016). Use of these data resulted in a dramatic increase in manufacturing output compared to the previous series, a tendency that is incompatible with other economic indicators.

15 The criteria for measuring GDP appear to have been changed to present the first Modi government in a better light than the previous one. This became evident when the government hastily removed from the website of the National Statistical Commission, a report by one of its own sub-committees that actually found average GDP growth during the previous Congress-led United Progressive Alliance (UPA) regime to have been higher. After taking this down, the CSO was forced to provide its own estimates of 
the past according to the new method of calculation, which then unsurprisingly suggested lower growth during UPA relative to the NDA government led by Modi. This move was so obvious that it destroyed credibility. Indeed, the Modi government's own former Chief Economic Adviser Arvind Subramanian came out with estimates based on disaggregated data using panel regressions that suggested that the methodological change had led to significant overestimation of GDP growth. Between 2011-2012 and 2016-2017, instead of an average annual GDP growth of 7 per cent as claimed by the official estimates, Subramanian argued that actual growth was only around 4.5 per cent on average.

The government's attitude towards survey data, which have formed the backbone of India's estimates of employment, poverty, and standards of living for more than six decades and were highly respected within and outside India, has been similarly destructive. The National Sample Survey Organisation (NSSO, a body within the CSO that conducts large-scale surveys) sought to move towards periodic labor force surveys that would provide more up-to-date data than the quinquennial surveys of employment and unemployment, the latest of which was carried out as long ago as 2011-2012. However, when the 2017-2018 survey was (belatedly) undertaken, the Modi government refused to allow the results to be published before the 2019 elections. Then, when they were finally released post-elections and showed a dramatic decline in employment (of around 9 million) as well as very significant increases in open unemployment (to average rates of more than 6 per cent), various Cabinet members repeatedly sought to denigrate the quality of the survey data. They ignorantly-and wrongly-claimed that the survey did not capture informal workers or gig workers, that it referred only to the unorganized sector, and made many other such completely false assertions. Thereafter they have sought simply to ignore the data of the Periodic Labour Force Surveys quarterly estimates as they have been released, since the data consistently show very poor employment generation and actual declines over this period.

The NSSO survey on consumption expenditure for 2017-2018 suffered an even worse fate: it was withdrawn altogether, and the Modi government has simply refused to release the data. However, a leaked report procured by journalists indicated alarming declines in rural consumption and significant increases in rural poverty between 2011-2012 and 2017-2018 (Subramanian 2019). As a result, the reason for official suppression of these data is only too obvious, despite the government claiming (without providing any justification) that the survey was methodologically faulty.

This strategy of sowing doubts about the work of purportedly independent statistical agencies obviously reduces their morale and dramatically undermines the public legitimacy of the statistical services. It reduces public scrutiny and accountability of the government, which this government has already been extremely wary of. (This is why it has hugely undercut the Right to Information Act by simply not filling vacancies of officers and only appointing those who would be amenable to official pressure). In addition, it has a major negative impact on public policymaking and implementation, because it means that the government itself is also in the dark about what is happening to the economy and the people. The rulers can remain confined to their own echo chamber of approval for economic policies that are either not working at all or are having very detrimental effects on the economy, and seek to manipulate public 
perception by using pliant mainstream media and its own army on social media to spread an opposite view of reality.

Similar stories can be told with respect to data on the environment, on the impact of the government's own policies and programs (for example, an official audit of the impact of the Ganga clean-up project has not been released) and various other data that are hugely important. Matters have deteriorated further during the Covid-19 pandemic when the government has sought to underestimate deaths from the disease, and suppressed the data usually released about total deaths, which would enable independent assessment of excess mortality over this period.

The close relationship between this particular brand of Hindu nationalism and an essentially neoliberal approach to the economy is captured by the government's focus on manipulating one particular indicator above all: the World Bank's Doing Business Index, which supposedly captures how "investment-friendly" the policies of a government are. This index has been both conceptually and operationally suspect since its inception in 2003, though mainstream economists have only recently started to criticize it. The World Bank's own Chief Economist, John Romer came out with a stinging criticism of it in 2018, arguing that most of the changes in country rankings over the previous four years resulted from repeated methodological changes that gave more weight to national governments' political orientation. This was both the result of ideological predilections of World Bank staff and intensive lobbying by particular governments-and the Modi government was particularly adept at this.

21 The government sought to improve India's rank in the index through various means, and bureaucrats were instructed to take necessary measures and publicize them, especially to World Bank officials (Deshmane 2018). The goal was to reach the "top 50" as soon as possible. Mostly this involved gaming the system, tinkering with small changes that would make a difference to the index without changing much on the ground. India rose dramatically in the rankings, from 142 in 2015 to 63 in the 2020 Index. Nevertheless, this was mostly achieved only by these regulatory fiddles rather than real policy changes. For example, small changes like eliminating the need for a company seal or rubber stamp to open a bank account, and eliminating the need to submit a cancelled cheque as part of the employee provident fund application process, had significant effects on the indicators that make up the index. In fact, it was shown by Sandefur and Wadhwa (2018) that the big changes in India's rank came from methodological changes in calculating the index rather than actual changes, and from rankings rather than actual scores. Because many countries perform similarly on the index, even small discrepancies in the score can produce wild swings in the rankings, which is what happened in India's case. But this has been touted as the Modi government's major economic success, even as the real economy and all the relevant indicators for the Indian population continue to plummet.

All this reinforces the argument that, at least as far as the economy is concerned, the Modi government is focused only on the management of perception rather than actually developing and implementing economic policies that would benefit the people. It remains to be seen how far this strategy can be taken: can the government continue to mislead and distract people with religious nationalism, or would a collapsing economy and declining livelihoods ultimately also affect the political appeal of Hindutva? 


\section{BIBLIOGRAPHY}

Deshmane, Akshay. 2018. "How Modi and Jaitley Gamed the World Bank's Doing Business Rankings." Huffington Post India, November 20. Retrieved on November 16, 2020 (https:// www.huffingtonpost.in/2018/11/20/how-modi-and-jaitley-gamed-the-world-banks-doingbusiness-rankings_a_23594375/?guccounter=1).

Nagaraj, R. 2015. "Seeds of Doubt on New GDP Numbers: Private Corporate Sector Overestimated?" Economic and Political Weekly L(13):14-17.

Sandefur, Justin and Divyanshi Wadhwa. 2018. "A Change in World Bank Methodology (Not Reform) Explains India's Rise in Doing Business Rankings." Center for Global Development, 5 February. Retrieved on November 16, 2020 (https://www.cgdev.org/blog/change-world-bankmethodology-not-reform-explains-indias-rise-doing-business).

Subramanian, Arvind. 2019. “India's GDP Mis-estimation: Likelihood, Magnitudes, Mechanisms, and Implications." Center for International Development, Faculty Working Paper No. 354. Retrieved on November 16, 2020 (https://www.hks.harvard.edu/centers/cid/publications/faculty-workingpapers/india-gdp-overestimate).

Subramanian, S. 2019. "What is Happening to Rural Welfare, Poverty, and Inequality in India?" The India Forum, December 6. Retrieved on November 16, 2020 (https://www.theindiaforum.in/ article/what-happened-rural-welfare-poverty-and-inequality-india-between-2011-12and-2017-18).

\section{ABSTRACTS}

This essay argues that attempts at implementing the Hindutva agenda adversely affect economic activity. At first sight, Modi's unabashedly neoliberal and pro-big capital claims could seem contradictory to his politics of hatred that severely disrupt economic growth. However, the ability of the government to persuade the public that the economy is doing well or that adverse outcomes are not the result of its own policies, actually serves the neoliberal agenda by taming the resentment of the poor and enabling further concentration of wealth. The Modi government is focused on the management of perception rather than on actually developing and implementing economic policies that would benefit the people. In this regard, manipulation and/ or destruction of the statistical system are decisive, which is why an aggressive attitude to economic statistics has become one of the defining features of the government.

INDEX

Keywords: neoliberalism, Hindutva, economic growth, statistics, manipulation, Narendra Modi

\section{AUTHOR}

JAYATI GHOSH

University of Massachusetts at Amherst, USA (formerly Jawaharlal Nehru University, New Delhi, India) 